\title{
Milestones in cardiovascular medicine: 10 or more?
}

\author{
E. E. van der Wall
}

Published online: 16 October 2013

(C) The Author(s) 2013. This article is published with open access at Springerlink.com

At the ESC Congress, Amsterdam, 30 August-4 September 2013, the world-known cardiologist Eugene Braunwald (Harvard, Boston, USA) presented the top-10 milestones in cardiovascular medicine. Let's have look at Braunwald's top-10 from cardiology history in chronological order. This list was also published in the ESC Congress News, 2 September, 2013 [1].

\section{1902. ELECTROCARDIOGRAPHY}

According to Braunwald, the birth of modern cardiology is 1902, when Willem Einthoven from Leiden, the Netherlands, recorded the first human electrocardiogram (ECG) with a string galvanometer he had developed to record electrical activity of the heart. Einthoven assigned the letters $\mathrm{P}, \mathrm{Q}, \mathrm{R}, \mathrm{S}$ and $\mathrm{T}$ to the various deflections and described the electrocardiographic features of a number of cardiovascular disorders.

\section{1927. CARDIAC CATHETERISATION}

Claude Bernard, the 19th century French physiologist, was the first to catheterise and measure pressures in the cardiac chambers and great vessels of animal hearts. A German surgical resident, Werner Forssman performed the first human catheterisation of the heart on himself in 1929. Later, in 1941, Andre Cournand, a French physiologist, and Dickinson Richards, an American, recorded intracardiac pressures and cardiac outputs in normal subjects and patients with congenital and acquired heart disease.

3. 1938/1953. CARDIOVASCULAR SURGERY

Modern cardiovascular surgery was first applied systematically in 1938 when Robert Gross from Boston

E. E. van der Wall $(\bowtie)$

Interuniversity Cardiology Institute of the Netherlands (ICIN), Netherlands Heart Institute (NHI), PO Box 19258, 3501 DG Utrecht, the Netherlands

e-mail: ernst.van.der.wall@icin.knaw.nl successfully closed a patent ductus arteriosus. In 1953 John Gibbon from Philadelphia performed the first openheart operation using cardiopulmonary bypass to successfully close an atrial septal defect. His design led to the construction of the heart-lung machine by IBM engineers.

4. 1952. ECHOCARDIOGRAPHY

In 1952 the Swedish team of cardiologist Inge Edler and physicist Helmuth Hertz adapted a sonar device developed to detect submarines in World War II for human use. The investigators provided continuous recordings of movements of the heart's walls and normal and diseased mitral valves.

5. 1952. PACEMAKERS AND INTERNAL DEFIBRILLATORS

In 1952 Paul Zoll from Boston developed the first external pacemaker, while in 1959 Rune Elmquist and Åke Senning from Zurich reported on the first successful use of internal pacemakers. In 1970 Michel Mirowski, an Israeli with dual training in cardiology and electrical engineering, working in Baltimore, invented the implanted cardioverter defibrillator (ICD). A steady drumbeat of successful clinical trials has greatly extended the indications for ICD implantation both in primary and secondary prevention of sudden cardiac death.

6. 1958. CORONARY ANGIOGRAPHY

Cardiac catheterisation paved the way for selective coronary arteriography, performed first in 1958 by Mason Sones of the Cleveland Clinic, who injected contrast dye directly into the coronary arteries, to image these vessels. This technique made possible coronary revascularisation, first surgical and then percutaneous.

7. 1961. PREVENTIVE CARDIOLOGY

Already in 1938 Paul Dudley White from Boston pioneered the concept of cardiovascular prevention. His advocacy led to the establishment of the Framingham Heart Study to identify coronary risk factors. In a 
paper published in 1961 investigators identified hypertension, smoking, and ECG evidence of left ventricular hypertrophy as risk factors. Based on these and other subsequently identified risk factors, the primary and secondary prevention of coronary artery disease (CAD) has been responsible for almost one-half of the $70 \%$ decline in age-adjusted deaths from CAD.

8. 1962. THE CORONARY CARE UNIT (CCU)

Desmond Julian, then a trainee at the Royal Infirmary in Edinburgh, first articulated the concept of CCUs in 1962. His vision foresaw acute myocardial infarct (AMI) patients together in the same unit, with continuous ECG monitoring, resuscitation equipment to hand, and specially trained staff on standby. The in-hospital mortality of AMI was immediately reduced by $50 \%$.

9. 1962. CARDIOVASCULAR DRUGS

In 1962 James Black, while working for ICI in the UK, developed beta-blocking agents to block the cardiac stimulating action of noradrenaline and reduce the heart's need for oxygen. The first angiotensinconverting enzyme inhibitor (ACE) captopril was isolated in the 1970s by Cushman and Ondetti while working at the Squibb Laboratories in the US. The first statin was isolated by Japanese biochemist Akira Endo of Sankyo Pharmaceuticals in 1976, and based on the LDLcholesterol pathway developed by Brown and Goldstein.

\section{1977. INVASIVE CARDIOLOGY}

Andreas Gruentzig, working in Zurich, expanded the use of cardiac catheters from diagnostic tools into powerful therapeutic devices. In 1977 he developed balloon angioplasty for expanding the lumens of narrowed arteries, which has been followed by stenting, first with bare metal stents and later with drug-eluting stents.

No one will doubt the important value of the top-10 milestones in cardiology as presented by Braunwald. These 10 milestones have definitively changed the cardiovascular landscape over time and moved the field into a new direction [2-6]. However, there have been many more milestones in cardiovascular medicine both in the eras before the 20th century and in the 20th century. I will shortly list 10 other milestones in cardiovascular medicine.

\section{1500. CARDIAC ANATOMY}

Leonardo da Vinci (1452-1519) was one of the first to anatomically study the vascular system by section of the human body. Da Vinci depicted detailed images of the heart and great vessels.

2. 1628. CIRCULATION

William Harvey (1578-1657), an English physician, was the first to describe completely and in detail the systemic circulation in 1628. Based on his discovery, Harvey has been considered to be one of the 10 most influential people of the second millennium.

\section{1816. PHYSICAL EXAMINATION}

René Théophile Hyacinthe Laennec (1781-1826) was a French physician who invented the stethoscope in 1816 in Paris, France. Needless to say that the stethoscope has become the most important 'conversation piece' of the clinician.

4. 1944. CONGENITAL HEART DISEASE SURGERY

Apart from the closure of a patent ductus arteriosus by Robert Gross in 1938, another historical milestone was performed in 1944 at the Johns Hopkins Hospital (Baltimore, USA) by the surgeon Alfred Blalock together with the cardiologist Helen Taussig and the technician Vivien Thomas by creating a connection between oxygen-rich and oxygen-deprived blood vessels to cure 'blue babies' (the so-called Blalock-Taussig shunt, being the separation of one branch of the subclavian artery or carotid artery and connection with the pulmonary artery).

5. 1976. CORONARY ARTERY BYPASS SURGERY (CABG)

In 1967, the cardiac surgeon René Favoloro (Argentina) performed the first documented saphenous aorto-coronary bypass graft (CABG) at the Cleveland Clinic (Ohio, USA) in a 51-year-old woman with total occlusion of the proximal third of the right coronary artery. Over the years, $\mathrm{CABG}$ has become the preferred treatment for disease of the left main coronary artery, disease of all three coronary vessels, diffuse disease not amenable to treatment with percutaneous coronary intervention.

6. 1967. HEART TRANSPLANT

In 1967, Dr. Christiaan Barnard became the first surgeon to perform a human-to-human heart transplant in Cape Town, South Africa. Although the procedure had a high mortality at the start, the current 10 -year survival rate is $70 \%$.

7. 1980 (and beyond). MODERN CARDIAC IMAGING

Although echocardiography revolutionised myocardial imaging in the 1970s (and still does)[7], today noninvasive cardiac imaging includes nuclear cardiology, magnetic resonance imaging and cardiac CT [8-10].

8. 1998. RADIOFREQUENCY CATHETER ABLATION (RFCA)

The first catheter ablation in humans was performed by Melvin Scheinman (San Francisco, USA) in 1981, using high-energy direct current shocks. This work has led directly to the development of radiofrequency catheter ablation (RFCA). In 1998, Michelle Haissaguerre, a cardiac electrophysiologist in Bordeaux, France first described the use of RFCA for patients with atrial fibrillation. The success rate of catheter ablation for atrial fibrillation is superior to the efficacy of antiarrhythmic drugs; sinus rhythm is restored in approximately $85 \%$ of cases at 1 year and $52 \%$ at 5 years. 


\section{2000.CARDIAC RESYNCHRONISATION THERAPY (CRT)}

In 2000, the benefits of cardiac resynchronisation therapy (CRT) were for the first time described by various scientific groups around the world as a new nonpharmacological modality to treat patients with heart failure. Most clinical CRT studies have shown decreases in hospitalisation and morbidity as well as improvements in quality of life.

10. 2002. TRANSCATHETER AORTIC VALVE IMPLANTATION (TAVI)

In 2002, the Frenchman Alain Cribier implanted the first transcatheter aortic valve in a patient at the University Hospital of Rouen, France, on 16 April 2002. More than 10 years after the first case, TAVI shows similar results to surgery in high-risk patients and superior results to medical therapy in inoperable patients.

Even this list is far from complete (just think of treatment of cardiomyopathies, channelopathies, Brugada syndrome, stem cell therapy, cardiogenetics), indicating the tremendous advances in the world of cardiology, cardiac surgery and paediatric cardiology over the years. To that purpose, a historical canon will be produced with 50 different windows, highlighting the most important achievements in cardiovascular medicine. The canon will be presented at the Annual Spring Congress of the NVVC, 3-4 April, Amsterdam, at the occasion of the 80-year anniversary of our annual society in 2014.
Open Access This article is distributed under the terms of the Creative Commons Attribution License which permits any use, distribution, and reproduction in any medium, provided the original author(s) and the source are credited.

\section{References}

1. ESC Congress News, Amsterdam, 2 September 2013.

2. Braunwald E. The Simon Dack lecture. Cardiology: the past, the present, and the future. J Am Coll Cardiol. 2003;42:2031-41.

3. Braunwald E. The rise of cardiovascular medicine. Eur Heart J. 2012;33:838-45. doi:10.1093/eurheartj/ehr452. 845a.

4. Nabel EG, Braunwald E. A tale of coronary artery disease and myocardial infarction. N Engl J Med. 2012;366:54-63. doi:10. 1056/NEJMra1112570.

5. van Hemel NM, van der Wall EE. 8 October 1958, D Day for the implantable pacemaker. Neth Heart J. 2008;16 Suppl 1:S3-4.

6. Bruschke AV, Sheldon WC, Shirey EK, et al. A half century of selective coronary arteriography. J Am Coll Cardiol. 2009;54: 2139-44. doi:10.1016/j.jacc.2009.06.0516.

7. van der Wall EE. Crown years for noninvasive cardiovascular imaging (part I): 60 years of echocardiography. Neth Heart J. 2013;21: 161-2. doi:10.1007/s12471-013-0381-3.

8. van der Wall EE. Crown years for non-invasive cardiovascular imaging (Part II): 40 years of nuclear cardiology. Neth Heart J. 2013;21: 211-3. doi:10.1007/s12471-013-0392-0.

9. van der Wall EE. Crown years for non-invasive cardiovascular imaging (Part III): 30 years cardiovascular magnetic resonance. Neth Heart J. 2013;21:263-5. doi:10.1007/s12471-013-0406-y.

10. van der Wall EE. Crown years for non-invasive cardiovascular imaging (Part IV): 30 years of cardiac computed tomography. Neth Heart J. 2013;21:315-8. doi:10.1007/s12471-013-0427-6. 